\title{
ON REGIONAL SHOCKS IN THE SPANISH ECONOMY
}

\author{
Adolfo Maza \\ University of Cantabria, Department of Economics, Santander, Spain
}

José Villaverde

University of Cantabria, Department of Economics, Santander, Spain

\begin{abstract}
It is well known that the nature of potential shocks impinging on a set of countries or regions may have important implications for relevant aspects of economic policy. This paper addresses the shocks issue empirically by applying the State Space methodology and the Kalman Filter to the case of the Spanish regions. The main conclusions are as follows: (i) it seems that the shocks affecting the Spanish regions have been mostly symmetric; (ii) their effects have been persistent rather than transitory; and (iii) supply shocks have been slightly more frequent than demand shocks.
\end{abstract}

\section{Introduction}

The surge in globalization that has taken place in the last few decades implies that most economies are more prone to suffer all kind of shocks. From a policy-oriented point of view it is vital to distinguish if a shock is symmetric or asymmetric, persistent or transitory, demand or supply-driven.

Although on an a priori basis, the most difficult situation for an economy is that related to asymmetric, persistent and supply-driven shocks (Emerson et al., 1992), a considerable number of empirical studies have mainly analyzed the symmetric or asymmetric nature of shocks. For our purposes, an asymmetric shock is defined as that affecting particular countries/regions in different ways. The bulk of the studies on asymmetric shocks made use of different methodologies, and were developed within the framework of the European Monetary Union.

The aim of this paper is to make a contribution to this strand of research by identifying the types of shocks that have impinged upon the Spanish regions for the period 1955-1997. The paper examines the symmetric or asymmetric nature of shocks as well as their persistence and origin. We use the State Space representation and the Kalman filter.

The remainder of this paper is organized into five sections. Section 2 briefly surveys the conventional contributions dealing with shocks and economic adjustment. Section 3 describes the empirical State Space model that we use to disentangle shocks to production and prices. Section 4 estimates the model and explores the potential asymmetric effects of common disturbances, while Section 5 analyzes the potential symmetric impact of specific shocks. Section 6 concludes. 


\section{Conventional approaches to shocks analysis}

Traditionally, three different approaches have been used to deal with the nature of shocks: correlation, trend adjustment and VAR (vector autoregression) approaches.

\section{I Correlation approach}

There has been extensive literature produced in the last few years that investigates whether potential shocks hitting economies have symmetrical or asymmetrical effects. The methodologies employed by researchers have varied considerably. Some authors have tried to ascertain whether a particular shock is symmetric or asymmetric by looking at the fluctuations of relevant economic variables. For example, they compute the correlation coefficients between the national and regional growth rates of these variables, or between a particular country (region) and a group of countries. If the correlation coefficient is high, then it can be inferred that those variables have not been affected by asymmetric shocks. For example, Fatás (1997) studied the asymmetries in the business cycles at the regional and national level for European Union (EU) countries. His basic finding is that national barriers have reduced the relative importance of asymmetric shocks over time. The correlation coefficient among regions of a single country has decreased, whereas the correlation among regions belonging to different countries has grown.

\subsection{Trend adjustment approach}

Cohen and Wyplosz (1989) pioneered an approach based upon the adjustment of a trend to some relevant economic series to ascertain the permanent or transitory nature of the shock. To do that, they transform all variables of interest into sums and differences, sums describing the aggregate economy and revealing symmetric shocks. Differences reveal, instead, asymmetric disturbances. This procedure has been widely used; Myro and Perelli (1996) and SánchezRobles and Cuñado (1999) all made use of this procedure in the Spanish case. The main finding of this research is that the probability of Spanish regions suffering asymmetric shocks does not appear to be very high.

\subsection{VAR approach}

VAR analysis offers a potential avenue of research for this issue. Blanchard and Quah (1989) were the first to apply the VAR methodology to this topic. It has also been employed by Bayoumi and Taylor (1992), Bayoumi and Eichengreen (1993) and Obstfeld and Peri (1998).

As is well known, to estimate VAR models it is necessary to impose some conditions on the set of contemporaneous interactions among variables. These restrictions determine which variables are affected in a period by shocks produced by other variables in the same period. There are no restrictions, however, on the remaining possible dynamic interactions: all variables may have an influence on and be affected by the others. The crucial assumption posed by these studies is, in most cases, that demand shocks have only temporary effects on output while supply shocks may have permanent consequences. ${ }^{1}$

\footnotetext{
${ }^{1}$ Nonetheless, some authors question this assumption (see, for instance, Bean, 1992).
} 
By using this line of research, Bayoumi and Eichengreen (1993), for example, find that the probability of European Union countries suffering asymmetric shocks is higher than for US States. Moreover, the response within the European Union to this kind of shock is slower than across the Atlantic.

\section{Shocks analysis: The State Space model and the Kalman filter approach}

The previous approaches, although interesting, have some important drawbacks. For example, the correlation approach is too naïve because it simply considers that the co-movement of two variables means that they are affected by symmetric shocks. As for the adjustment of a trend to the time series, this approach does not provide the researcher with clear information about the shock's degree of symmetry and its persistence. In contrast, the main shortcoming of the VAR procedure is related to the assumptions that are necessary in order to identify the model, upon which the conclusions are crucially dependent; these assumptions (usually restrictions on the contemporaneous relationships among the shocks or/and their effects on other shocks) can be sometimes regarded as ad hoc.

Taking into consideration the drawbacks that exist in the methodologies reviewed in section 2, in this section we present the State Space representation and the Kalman filter as a way to overcome the aforementioned drawbacks. In addition, this approach allows us to identify the origin (demand or supply) of the shock.

\section{I State Space and the Kalman filter approach: A general model}

This approach to time series analysis consists, basically, of transforming the initial model into another one, the so-called State Space model (e.g. Gregory et al., 1997; Jansson, 1997). A particular algorithm, such as the Kalman filter, is then applied in order to estimate the parameters. One important property of the Kalman filter is that it updates the system sequentially. The Kalman filter is encompassed by a set of equations that allow an estimator to be recalculated when new information is available. First, the equations are estimated to obtain the optimal prediction of the next observation, given the information available at that moment. Next, when the new information is received and by means of the actualization equations, the predictions are revised. As a result, the errors of previous predictions are employed to construct the likelihood function according to which the corresponding parameters are estimated.

In general terms, ${ }^{2}$ the State Space model consists of two equations. The first one is the measure equation, which relates a set of endogenous observable variables, denoted by $y_{t}$, to a collection of exogenous variables $d_{t}$, also observable, and a set of non-observable elements, $\alpha_{t}$, known as the vector of spaces. More formally,

$$
y_{t}=Z_{t} \alpha_{t}+d_{t}+\varepsilon_{t}
$$

where $Z_{t}$ is a matrix of parameters associated to the vector of spaces $\alpha_{t}$ and $\varepsilon_{t}$ is a vector of serially uncorrelated residuals, with zero mean and $H_{t}$ covariance matrix.

\footnotetext{
${ }^{2}$ For a thorough description of this kind of analysis, see Harvey (1989) or Hamilton (1994).
} 
The second equation is called the transition equation. It describes the behavior over time of the vector of spaces. In particular, and although it is not observable, we can assume that it is generated by a first order Markov process.

$$
\alpha_{t}=T_{t} \alpha_{t-1}+c_{t}+R_{t} \eta_{t}
$$

where $T_{t}$ is a matrix of parameters, $c_{t}$ is encompassed by exogenous, observable variables, and $R_{t}$ is the matrix associated to the vector of residuals $\left(\eta_{t}\right)$, which is in turn serially uncorrelated, with zero mean and $Q_{t}$ covariance matrix.

Once the State Space representation of the model is obtained, we can apply several algorithms to estimate its parameters. However, the most widely used, as mentioned here, is the Kalman filter.

\subsection{The State Space and the Kalman filter approach: A particular model ${ }^{3}$}

Having presented a general model, we now adapt it to analyzing the fluctuations experienced by output and prices in the various Spanish regions. In so doing, we denote by $X_{i t}$ the series of output (y) and prices ( $\mathrm{p}$ ) for the region $i$ in period $t$ once the trend has been removed. Next, these series are disentangled in two non-observable components: the first one $\left(X_{t}^{C}\right)$ is common for all regions and the second $\left(X_{i t}^{S}\right)$ is specific for each region. Analytically, the measure equation is

$$
X_{i t}=\gamma_{i} X_{t}^{C}+X_{i t}^{S}
$$

where $\gamma_{i}$ reflects the impact of a common shock in region $i$. The main problem when performing the estimation of equation (1) is that the two components of $X_{i t}$ cannot be directly observed. However, under certain assumptions (in particular, that they are independent and that their behavior is known) they can be estimated. Moreover, we subject equation (1) to stochastic shocks. Thus, it is assumed that the non-observable components follow a first order autoregressive process described by the following transition equations:

$$
\begin{aligned}
& X_{t}^{C}=\alpha X_{t-1}^{C}+\varepsilon_{t}^{C} \\
& X_{i t}^{S}=\beta_{i} X_{i t-1}^{S}+\varepsilon_{i t}^{S}
\end{aligned}
$$

where $\varepsilon_{t}^{C}$ and $\varepsilon_{i t}^{S}$ represent the common and specific shocks respectively. It seems reasonable to assume that the common component captures the symmetric shocks, whereas the region-specific component reflects the asymmetric shocks. Nevertheless, this assumption will be relaxed in the following sections.

We also assume that the shocks follow a normal distribution, with zero mean and constant variance. Asymmetric shocks are uncorrelated among themselves $\left(\operatorname{Cov}\left(\varepsilon_{i t}^{S}, \varepsilon_{j t}^{S}\right)=0\right.$ for all $i \neq j)$ and with symmetric shocks $\left(\operatorname{Cov}\left(\varepsilon_{i t}^{S}, \varepsilon_{t}^{C}\right)=0\right.$ for all $\left.i\right)$.

Once the State Space model has been specified, the next step is to apply the Kalman filter in order to estimate its parameters. This is a recursive procedure for computing the optimal

\footnotetext{
${ }^{3}$ Model diagnosis is shown in the appendix.
} 
estimator of the non-observable components in period $t$, based upon information available in that same period.

Thus, the estimation of this model allows us to identify the type of shock impinging upon the economy. First, as regards persistence, it is known that the values of the parameters associated with the lags of the dependent variable in equation (2) provide information on the degree of persistence of a disturbance. Because this is an AR(1) process, the closer to unity the parameter associated with the first lag, the more persistent the shocks.

Moreover, in order to ascertain the importance of common (or symmetric) and specific (or asymmetric) shocks, the variance of the original series has been decomposed as follows:

$$
\operatorname{Var}\left(X_{i t}\right)=\gamma_{i}^{2} \operatorname{Var}\left(X_{t}^{C}\right)+\operatorname{Var}\left(X_{i t}^{S}\right)
$$

where

$$
\begin{aligned}
& \operatorname{Var}\left(X_{t}^{C}\right)=\operatorname{Var}\left(\varepsilon_{t}^{C}\right)+\alpha \operatorname{Cov}\left(X_{t}^{C}, X_{t-1}^{C}\right) \\
& \operatorname{Var}\left(X_{i t}^{S}\right)=\operatorname{Var}\left(\varepsilon_{i t}^{S}\right)+\beta_{i} \operatorname{Cov}\left(X_{i t}^{S}, X_{i t-1}^{S}\right)
\end{aligned}
$$

By applying this decomposition, the percentages of the change in $X_{i t}$ that are explained by symmetric and asymmetric shocks can be computed.

We still have to identify demand shocks and supply shocks. This is important from a policyoriented point of view because a supply-side shock is much more difficult to deal with than a demand-driven shock. The model itself does not provide an answer to this question, but some information can be ascertained by examining the error terms. In particular, it is possible to disentangle the disturbances into demand and supply shocks as follows. For the level of output the expressions are:

$$
\begin{aligned}
& \varepsilon_{t}^{C}(y)=\alpha^{y} D_{t}^{C}+\beta^{y} S_{t}^{C} \\
& \varepsilon_{i t}^{S}(y)=\delta_{i}^{y} D_{i t}^{S}+\gamma_{i}^{y} S_{i t}^{S}
\end{aligned}
$$

and for the price level:

$$
\begin{aligned}
& \varepsilon_{t}^{C}(p)=\alpha^{p} D_{t}^{C}+\beta^{p} S_{t}^{C} \\
& \varepsilon_{i t}^{S}(p)=\delta_{i}^{p} D_{i t}^{S}+\gamma_{i}^{p} S_{i t}^{S}
\end{aligned}
$$

where $D_{t}^{C}\left(D_{i t}^{S}\right)$ represent the symmetric (asymmetric) demand shocks and $S_{t}^{C}\left(S_{i t}^{S}\right)$ represent the symmetric (asymmetric) supply disturbances. Since these shocks are structural, the $\operatorname{Cov}\left(Z_{t}, Y_{t}\right)$ is equal to zero for all $Z_{t} \neq Y_{t}$, where $Z_{t}, Y_{t}=D_{t}^{C}, D_{i t}^{S}, S_{t}^{C}, S_{i t}^{S}$.

To identify these shocks it is assumed that the sign of the impact of the demand shocks is the same for output and prices, whereas supply shocks have opposite effects on these variables. Thus, the sign of the parameters can be determined. As for an output shock, either demand or supply driven, has the same effect, it can be said that $\alpha^{y}, \delta_{i}^{y}>0 ; \beta^{y}, \gamma_{i}^{y}>0$. However, as for the price level, supply and demand shocks have opposite effects, it happens that if $\alpha^{p}, \delta_{i}^{p}>0$, 
Figure 1. The Spanish regions.

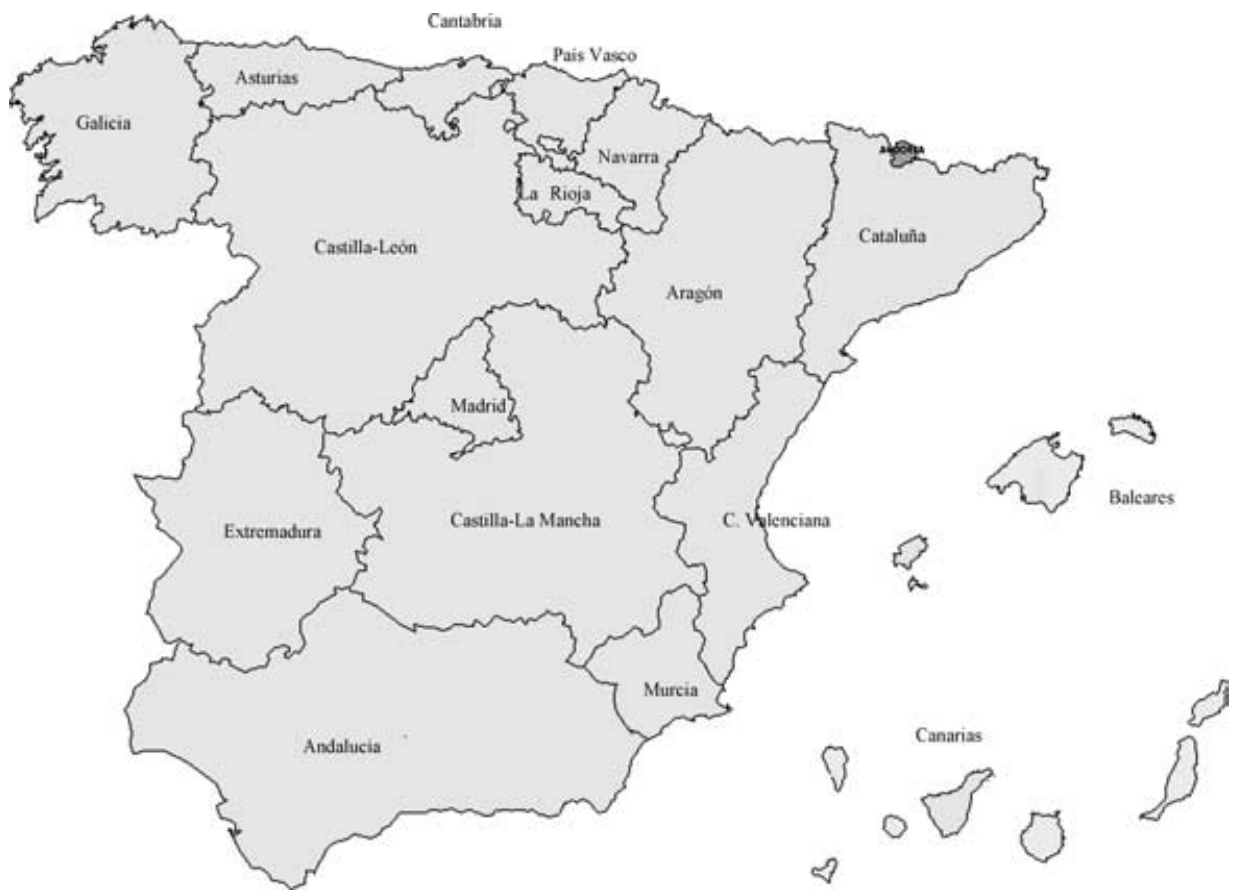

then $\beta^{p}, \gamma_{i}^{p}<0$. Subsequently, it is easily seen that, because

$$
\begin{aligned}
& \operatorname{Cov}\left(\varepsilon_{t}^{C}(y), \varepsilon_{t}^{C}(p)\right)=\alpha^{y} \alpha^{p} \operatorname{Var}\left(D_{t}^{C}\right)+\beta^{y} \beta^{p} \operatorname{Var}\left(S_{t}^{C}\right) \\
& \operatorname{Cov}\left(\varepsilon_{i t}^{S}(y), \varepsilon_{i t}^{S}(p)\right)=\delta_{i}^{y} \delta_{i}^{p} \operatorname{Var}\left(D_{i t}^{S}\right)+\gamma_{i}^{y} \gamma_{i}^{p} \operatorname{Var}\left(S_{i t}^{S}\right)
\end{aligned}
$$

the sign of the correlation coefficient between the estimated error terms gives information on the importance of supply and demand shocks. A positive (negative) sign indicates that demand (supply) shocks are predominant.

\section{The State Space and the Kalman filter approach: Application to the Spanish regions}

In this section we are going to apply the State Space approach for the case of the Spanish regions (Figure 1) during the period 1955-1997 using data for gross added value (GAV), in millions of constant (1986) pesetas, and the series of implicit price indexes on GAV, developed by the Fundación Bilbao Vizcaya Argentaria (BBVA). These series have been detrended by means of differentiating their $\log$ values $^{4}$ to make them stationary.

\footnotetext{
${ }^{4}$ More specifically, the series employed are $X_{i t}=\left[\Delta \log \left(G A V_{i t}\right)-\mathrm{E}\left(\Delta \log \left(G A V_{i t}\right)\right)\right]$ and $X_{i t}=\left[\Delta^{2} \log \left(P_{i t}\right)\right.$ $\left.-\mathrm{E}\left(\Delta^{2} \log \left(P_{i t}\right)\right)\right]$ for the GAV and price index $\mathrm{P}$, respectively, where $\Delta$ is the lag operator.
} 


\section{I Main results}

The results obtained in equations (1) and (2) are displayed in Table 1. The first two columns show how the common component affects fluctuations in output and prices in all regions [Equation (1)]. The results have been normalized and the sensitivity of output and price fluctuations relative to the common component of Madrid has been set to 1 . This means that if the coefficient for a particular region is greater (less) than 1, that region is more (less) vulnerable to common shocks than Madrid. Values in parentheses are $P$-values, computed by means of the likelihood ratio test (Harvey, 1990). They can be interpreted, under the null hypothesis, as the probability of a region not being influenced by the common component.

The main results provide evidence that changes in the common coefficient affect all regions. The point estimates of the coefficients are mostly close to 1, and they are significant in all cases. However, it seems that some regions react in quite a different way to this kind of shock. This aspect will be further discussed in the next section.

The remaining columns of Table 1 show the degree of persistence of a shock [Equation (2)]. Recall that the closer the coefficient is to 1 in absolute terms, the more persistent is the shock. If the coefficient is zero, then the shock may be regarded as purely transitory. The results show that the impact of symmetric shocks ${ }^{5}$ is quite persistent on output and less on prices. In contrast, the findings are less homogeneous as far as asymmetric shocks are concerned. It can also be seen that these asymmetric shocks are more persistent on output than on prices. For output, the probability of these shocks being fully transitory is especially small for País Vasco, Canarias and Asturias, whereas the probability is large for Castilla-León and Cantabria. In terms of prices, Madrid shows the highest level of persistence, followed by Cantabria and Castilla-La Mancha. Again, the converse is true for Aragón and the País Vasco, where the probability of these shocks being fully transitory is higher than $90 \%$. Generally speaking, it can be concluded that there is no apparent spatial pattern to the persistence of asymmetric shocks.

Table 2 identifies symmetric and asymmetric shocks by employing the variance decomposition technique described above [Equations (3) and (4)]. The table also presents a ranking of the regions, with Comunidad Valenciana (for output) and Cataluña (for prices) with the label 1 , that is, the regions with the smallest probability of being hit by an asymmetric disturbance. It can be seen that symmetric shocks are more important in the majority of regions than asymmetric shocks. This is especially the case for prices, which are clearly important in relation to competitiveness and the cost structure of firms. Regions where asymmetric shocks are less relevant are Comunidad Valenciana, Cataluña and Aragón (for output) and Cataluña, Comunidad Valenciana, Madrid, Murcia and Aragón (for prices). However, in some specific regions, asymmetric shocks play a prominent role: in particular, Asturias (both for output and prices) and Extremadura (for output). On the whole, two conclusions can be reached. First, asymmetric shocks are less important in the eastern, more advanced regions of Spain than in the rest of the country. In contrast, asymmetric shocks are more relevant in some regions in which the industrial mix is very different to the national average.

Finally, we consider whether the disturbances are demand or supply driven by examining the correlations among the shocks in output and prices [Equation (6)]. The outcomes are presented in Table 3. The first one is that in most cases the coefficient is not statistically significant, meaning that there is no clear pattern as to the origin of the shock. However, in those cases

\footnotetext{
${ }^{5}$ Shocks in the common component.
} 
Table 1. Shocks persistence

\begin{tabular}{|c|c|c|c|c|c|c|}
\hline \multirow[t]{2}{*}{ Regions } & \multicolumn{2}{|c|}{$\begin{array}{c}\text { Sensitivity to the } \\
\text { symmetric component } \\
\gamma_{i}\end{array}$} & \multicolumn{2}{|c|}{$\begin{array}{c}\text { Persistence of } \\
\text { symmetric shocks } \\
\alpha\end{array}$} & \multicolumn{2}{|c|}{$\begin{array}{c}\text { Persistence of } \\
\text { asymmetric shocks } \\
\beta_{i}\end{array}$} \\
\hline & GAV & Prices & GAV & Prices & GAV & Prices \\
\hline Andalucía & $\begin{array}{l}1.11 \\
(0.0000)\end{array}$ & $\begin{array}{l}0.93 \\
(0.0000)\end{array}$ & $\begin{array}{l}0.76 \\
(0.0000)\end{array}$ & $\begin{array}{l}0.44 \\
(0.0165)\end{array}$ & $\begin{array}{l}0.54 \\
(0.0157)\end{array}$ & $\begin{array}{l}0.31 \\
(0.1680)\end{array}$ \\
\hline Aragón & $\begin{array}{l}1.34 \\
(0.0000)\end{array}$ & $\begin{array}{l}0.79 \\
(0.0000)\end{array}$ & $\begin{array}{l}0.76 \\
(0.0000)\end{array}$ & $\begin{array}{l}0.44 \\
(0.0165)\end{array}$ & $\begin{array}{l}0.55 \\
(0.0956)\end{array}$ & $\begin{array}{l}0.02 \\
(0.9356)\end{array}$ \\
\hline Asturias & $\begin{array}{l}0.72 \\
(0.0039)\end{array}$ & $\begin{array}{l}0.61 \\
(0.0007)\end{array}$ & $\begin{array}{l}0.76 \\
(0.0000)\end{array}$ & $\begin{array}{l}0.44 \\
(0.0165)\end{array}$ & $\begin{array}{l}0.63 \\
(0.0005)\end{array}$ & $\begin{array}{l}0.25 \\
(0.2402)\end{array}$ \\
\hline Baleares & $\begin{array}{l}1.23 \\
(0.0000)\end{array}$ & $\begin{array}{l}0.99 \\
(0.0000)\end{array}$ & $\begin{array}{l}0.76 \\
(0.0000)\end{array}$ & $\begin{array}{l}0.44 \\
(0.0165)\end{array}$ & $\begin{array}{l}0.60 \\
(0.0015)\end{array}$ & $\begin{array}{l}-0.07 \\
(0.7440)\end{array}$ \\
\hline Canarias & $\begin{array}{l}1.22 \\
(0.0000)\end{array}$ & $\begin{array}{l}1.01 \\
(0.0000)\end{array}$ & $\begin{array}{l}0.76 \\
(0.0000)\end{array}$ & $\begin{array}{l}0.44 \\
(0.0165)\end{array}$ & $\begin{array}{l}0.66 \\
(0.0003)\end{array}$ & $\begin{array}{l}0.10 \\
(0.6415)\end{array}$ \\
\hline Cantabria & $\begin{array}{l}1.25 \\
(0.0000)\end{array}$ & $\begin{array}{l}0.70 \\
(0.0000)\end{array}$ & $\begin{array}{l}0.76 \\
(0.0000)\end{array}$ & $\begin{array}{l}0.44 \\
(0.0165)\end{array}$ & $\begin{array}{l}0.33 \\
(0.1074)\end{array}$ & $\begin{array}{l}0.35 \\
(0.1084)\end{array}$ \\
\hline Castilla-León & $\begin{array}{l}0.91 \\
(0.0000)\end{array}$ & $\begin{array}{l}0.79 \\
(0.0000)\end{array}$ & $\begin{array}{l}0.76 \\
(0.0000)\end{array}$ & $\begin{array}{l}0.44 \\
(0.0165)\end{array}$ & $\begin{array}{c}0.38 \\
(0.1527)\end{array}$ & $\begin{array}{c}0.16 \\
(0.4076)\end{array}$ \\
\hline Castilla-La Mancha & $\begin{array}{l}1.18 \\
(0.0000)\end{array}$ & $\begin{array}{l}0.70 \\
(0.0000)\end{array}$ & $\begin{array}{l}0.76 \\
(0.0000)\end{array}$ & $\begin{array}{l}0.44 \\
(0.0165)\end{array}$ & $\begin{array}{l}0.56 \\
(0.0053)\end{array}$ & $\begin{array}{l}0.30 \\
(0.1278)\end{array}$ \\
\hline Cataluña & $\begin{array}{l}1.47 \\
(0.0000)\end{array}$ & $\begin{array}{l}0.86 \\
(0.0000)\end{array}$ & $\begin{array}{l}0.76 \\
(0.0000)\end{array}$ & $\begin{array}{l}0.44 \\
(0.0165)\end{array}$ & $\begin{array}{l}0.46 \\
(0.0367)\end{array}$ & $\begin{array}{l}0.08 \\
(0.7347)\end{array}$ \\
\hline Comunidad Valenciana & $\begin{array}{l}1.43 \\
(0.0000)\end{array}$ & $\begin{array}{l}0.78 \\
(0.0000)\end{array}$ & $\begin{array}{l}0.76 \\
(0.0000)\end{array}$ & $\begin{array}{l}0.44 \\
(0.0165)\end{array}$ & $\begin{array}{l}0.82 \\
(0.0601)\end{array}$ & $\begin{array}{l}0.25 \\
(0.2634)\end{array}$ \\
\hline Extremadura & $\begin{array}{l}0.83 \\
(0.0026)\end{array}$ & $\begin{array}{l}0.79 \\
(0.0000)\end{array}$ & $\begin{array}{l}0.76 \\
(0.0000)\end{array}$ & $\begin{array}{l}0.44 \\
(0.0165)\end{array}$ & $\begin{array}{l}0.53 \\
(0.0067)\end{array}$ & $\begin{array}{l}-0.14 \\
(0.5443)\end{array}$ \\
\hline Galicia & $\begin{array}{l}1.10 \\
(0.0000)\end{array}$ & $\begin{array}{l}0.74 \\
(0.0000)\end{array}$ & $\begin{array}{l}0.76 \\
(0.0000)\end{array}$ & $\begin{array}{l}0.44 \\
(0.0165)\end{array}$ & $\begin{array}{l}0.68 \\
(0.0018)\end{array}$ & $\begin{array}{l}-0.15 \\
(0.5648)\end{array}$ \\
\hline Madrid & $\begin{array}{l}1.00 \\
(-)\end{array}$ & $\begin{array}{l}1.00 \\
(-)\end{array}$ & $\begin{array}{l}0.76 \\
(0.0000)\end{array}$ & $\begin{array}{l}0.44 \\
(0.0165)\end{array}$ & $\begin{array}{l}0.70 \\
(0.0010)\end{array}$ & $\begin{array}{l}0.46 \\
(0.0090)\end{array}$ \\
\hline Murcia & $\begin{array}{l}1.04 \\
(0.0000)\end{array}$ & $\begin{array}{l}0.80 \\
(0.0000)\end{array}$ & $\begin{array}{l}0.76 \\
(0.0000)\end{array}$ & $\begin{array}{l}0.44 \\
(0.0165)\end{array}$ & $\begin{array}{l}0.64 \\
(0.0013)\end{array}$ & $\begin{array}{l}0.10 \\
(0.5006)\end{array}$ \\
\hline Navarra & $\begin{array}{l}1.23 \\
(0.0000)\end{array}$ & $\begin{array}{l}0.75 \\
(0.0000)\end{array}$ & $\begin{array}{l}0.76 \\
(0.0000)\end{array}$ & $\begin{array}{l}0.44 \\
(0.0165)\end{array}$ & $\begin{array}{l}0.52 \\
(0.0061)\end{array}$ & $\begin{array}{l}0.11 \\
(0.5188)\end{array}$ \\
\hline País Vasco & $\begin{array}{l}1.18 \\
(0.0000)\end{array}$ & $\begin{array}{l}0.68 \\
(0.0000)\end{array}$ & $\begin{array}{l}0.76 \\
(0.0000)\end{array}$ & $\begin{array}{l}0.44 \\
(0.0165)\end{array}$ & $\begin{array}{l}0.74 \\
(0.0001)\end{array}$ & $\begin{array}{l}0.02 \\
(0.9184)\end{array}$ \\
\hline Rioja (La) & $\begin{array}{l}0.98 \\
(0.0000)\end{array}$ & $\begin{array}{l}0.84 \\
(0.0000)\end{array}$ & $\begin{array}{l}0.76 \\
(0.0000)\end{array}$ & $\begin{array}{l}0.44 \\
(0.0165)\end{array}$ & $\begin{array}{l}0.66 \\
(0.0008)\end{array}$ & $\begin{array}{l}0.10 \\
(0.6324)\end{array}$ \\
\hline
\end{tabular}

Notes: $P$ in parentheses.

The null hypotheses are:

$$
\begin{aligned}
& \mathrm{H}_{0}: \gamma_{i}=0 \\
& \mathrm{H}_{0}: \alpha=0 \\
& \mathrm{H}_{0}: \beta_{i}=0
\end{aligned}
$$

Source: Fundación BBVA and own elaboration.

where the coefficients are statistically different from zero, supply shocks seem to have been relatively more important than demand shocks. Andalucía exhibits the highest negative correlation $(-0.67)$, followed by the País Vasco, Castilla-León and Madrid. Regions that have been hit by demand shocks are Extremadura and Comunidad Valenciana. 
Table 2. Decomposition into symmetric and asymmetric shocks (\%)

\begin{tabular}{|c|c|c|c|c|c|c|}
\hline \multirow[t]{2}{*}{ Regions } & \multicolumn{2}{|c|}{ Symmetric component } & \multicolumn{2}{|c|}{ Asymmetric component } & \multicolumn{2}{|c|}{ Ranking } \\
\hline & GAV & Prices & GAV & Prices & GAV & Prices \\
\hline Andalucía & 84.76 & 90.23 & 15.24 & 9.77 & 6 & 8 \\
\hline Aragón & 95.38 & 95.33 & 4.62 & 4.67 & 3 & 5 \\
\hline Asturias & 39.71 & 49.21 & 60.29 & 50.79 & 17 & 17 \\
\hline Baleares & 79.85 & 76.20 & 20.15 & 23.80 & 8 & 16 \\
\hline Canarias & 70.07 & 88.36 & 29.93 & 11.64 & 13 & 12 \\
\hline Cantabria & 75.15 & 92.62 & 24.85 & 7.38 & 12 & 6 \\
\hline Castilla-León & 77.41 & 88.90 & 22.59 & 11.10 & 11 & 9 \\
\hline Castilla-La Mancha & 78.39 & 88.83 & 21.61 & 11.17 & 9 & 10 \\
\hline Cataluña & 95.92 & 98.19 & 4.08 & 1.81 & 2 & 1 \\
\hline Comunidad Valenciana & 97.13 & 98.07 & 2.87 & 1.93 & 1 & 2 \\
\hline Extremadura & 47.43 & 83.53 & 52.57 & 16.47 & 16 & 14 \\
\hline Galicia & 94.28 & 87.49 & 5.72 & 12.51 & 4 & 13 \\
\hline Madrid & 69.88 & 97.53 & 30.12 & 2.47 & 14 & 3 \\
\hline Murcia & 77.74 & 95.47 & 22.26 & 4.53 & 10 & 4 \\
\hline Navarra & 81.99 & 88.46 & 18.01 & 11.54 & 7 & 11 \\
\hline País Vasco & 59.87 & 82.03 & 40.13 & 17.97 & 15 & 15 \\
\hline Rioja (La) & 86.84 & 92.49 & 13.16 & 7.51 & 5 & 7 \\
\hline
\end{tabular}

Sources: Fundación BBVA and own elaboration.

Table 3. Demand and supply shocks

\begin{tabular}{lc}
\hline Regions & $\begin{array}{c}\text { Correlation coefficient } \\
\text { among shocks }\end{array}$ \\
\hline Common component & 0.08 \\
Andalucía & $-0.67^{*}$ \\
Aragón & -0.19 \\
Asturias & -0.17 \\
Baleares & 0.23 \\
Canarias & -0.09 \\
Cantabria & 0.08 \\
Castilla-León & $-0.32^{*}$ \\
Castilla-La Mancha & -0.15 \\
Cataluña & 0.25 \\
Comunidad Valenciana & $0.31^{*}$ \\
Extremadura & $0.44^{*}$ \\
Galicia & 0.20 \\
Madrid & $-0.29^{*}$ \\
Murcia & -0.21 \\
Navarra & -0.14 \\
País Vasco & $-0.38^{*}$ \\
Rioja (La) & -0.22 \\
\hline
\end{tabular}

Note: *significant at $95 \%$.

Source: Fundación BBVA and own elaboration.

\subsection{Could common shocks have asymmetric effects?}

Up to now, we have assumed that common shocks produce symmetric effects, thus they have been considered tantamount to symmetric shocks. It could be possible, however, that a common shock has similar (symmetric) effects in some regions and a different (asymmetric) 
impact in others (e.g. Blanchard and Wolfers, 1999). This would be the case if, for example, the industry mix is dissimilar among regions. We address this issue in this section.

Accordingly, we examine if a common shock may behave as an asymmetric disturbance. To do that, we repeat the exercise of the previous section, but now impose the same coefficient associated with the common component of the shock for all regions. ${ }^{6}$ In analytical terms, the following measure equation is estimated:

$$
X_{i t}=\gamma X_{t}^{C}+X_{i t}^{S}
$$

where the $\gamma$ coefficient captures the average response of the country to this type of shock. Once this coefficient is estimated, the potential asymmetric effects of a common shock can be approximated by computing the probability of each region responding in an identical way as the country. In other words, the model is estimated under the null hypothesis that the coefficient for each region $\left(\gamma_{i}\right)$ is the same as the national coefficient $(\gamma)$. High $P$-values mean that the probability of a common shock having an asymmetric impact will be low.

Estimates of equation (7) are displayed in Table 4 (to make results comparable with those obtained previously, the coefficient of Madrid is again considered equal to 1). The estimated output coefficient is 1.20. Thus, the common component has a decisive influence in the output fluctuations because the probability of this coefficient being zero is null. As far as the price level is concerned, Table 4 shows that the coefficient on the common component is estimated to be 0.79 and highly significant. In contrast, the results on the persistence of shocks, both for output and prices, do not differ to a great extent from those obtained in the previous section.

Now, in order to approximate the probability of a common shock having different effects on the Spanish regions, we compare the response of each region to that obtained for the country as a whole. The results are given in Table 5.

The first column of the table shows that the response of output is very different in Asturias compared to the rest of the Spanish regions. Other regions reacting somewhat differently from the national norm are Cataluña, Extremadura, Castilla-León and Comunidad Valenciana. The opposite holds true for the País Vasco, Castilla-La Mancha and Canarias; the probability of the response of these three regions being identical to national is large. The second column of Table 5 shows that, in terms of prices, regions such as Canarias, Cataluña, Cantabria and Andalucía react quite differently from the nation. In contrast, the sensitivity of Aragón, Extremadura and Castilla-León to the common component is analogous to the national one. Once again, a clear spatial pattern emerges neither on output nor on prices.

Finally, when both variables are considered at the same time, the null hypothesis (at the 5\% significance level) of common shocks having symmetric effects in most Spanish regions (apart from Canarias for prices), cannot be rejected.

\section{Could specific shocks have symmetric effects?}

In Section 4 the fluctuations experienced by each one of the Spanish regions was disentangled into common and specific shocks. At that point we identified specific shocks with

\footnotetext{
${ }^{6}$ This generalization increases the proportion of variance attributable to common rather than regional shocks. For reasons of clarity, these results are omitted.
} 
Table 4. Restricted model

\begin{tabular}{|c|c|c|c|c|c|c|}
\hline \multirow[t]{2}{*}{ Regions } & \multicolumn{2}{|c|}{$\begin{array}{c}\text { Sensitivity to the } \\
\text { symmetric component } \\
\gamma\end{array}$} & \multicolumn{2}{|c|}{$\begin{array}{c}\text { Persistence of } \\
\text { symmetric shocks } \\
\alpha\end{array}$} & \multicolumn{2}{|c|}{$\begin{array}{c}\text { Persistence of } \\
\text { asymmetric shocks } \\
\beta_{i}\end{array}$} \\
\hline & GAV & Prices & GAV & Prices & GAV & Prices \\
\hline Andalucía & $\begin{array}{l}1.20 \\
(0.0000)\end{array}$ & $\begin{array}{l}0.79 \\
(0.0000)\end{array}$ & $\begin{array}{l}0.77 \\
(0.0000)\end{array}$ & $\begin{array}{l}0.45 \\
(0.0139)\end{array}$ & $\begin{array}{l}0.55 \\
(0.0150)\end{array}$ & $\begin{array}{l}0.23 \\
(0.2968)\end{array}$ \\
\hline Aragón & $\begin{array}{l}1.20 \\
(0.0000)\end{array}$ & $\begin{array}{l}0.79 \\
(0.0000)\end{array}$ & $\begin{array}{l}0.77 \\
(0.0000)\end{array}$ & $\begin{array}{l}0.45 \\
(0.0139)\end{array}$ & $\begin{array}{l}0.28 \\
(0.2228)\end{array}$ & $\begin{array}{l}0.01 \\
(0.9501)\end{array}$ \\
\hline Asturias & $\begin{array}{l}1.20 \\
(0.0000)\end{array}$ & $\begin{array}{l}0.79 \\
(0.0000)\end{array}$ & $\begin{array}{l}0.77 \\
(0.0000)\end{array}$ & $\begin{array}{l}0.45 \\
(0.0139)\end{array}$ & $\begin{array}{l}0.56 \\
(0.0018)\end{array}$ & $\begin{array}{l}0.18 \\
(0.3932)\end{array}$ \\
\hline Baleares & $\begin{array}{l}1.20 \\
(0.0000)\end{array}$ & $\begin{array}{l}0.79 \\
(0.0000)\end{array}$ & $\begin{array}{l}0.77 \\
(0.0000)\end{array}$ & $\begin{array}{l}0.45 \\
(0.0139)\end{array}$ & $\begin{array}{l}0.59 \\
(0.0019)\end{array}$ & $\begin{array}{l}0.07 \\
(0.7280)\end{array}$ \\
\hline Canarias & $\begin{array}{l}1.20 \\
(0.0000)\end{array}$ & $\begin{array}{l}0.79 \\
(0.0000)\end{array}$ & $\begin{array}{l}0.77 \\
(0.0000)\end{array}$ & $\begin{array}{l}0.45 \\
(0.0139)\end{array}$ & $\begin{array}{l}0.66 \\
(0.0002)\end{array}$ & $\begin{array}{l}0.18 \\
(0.3259)\end{array}$ \\
\hline Cantabria & $\begin{array}{l}1.20 \\
(0.0000)\end{array}$ & $\begin{array}{l}0.79 \\
(0.0000)\end{array}$ & $\begin{array}{l}0.77 \\
(0.0000)\end{array}$ & $\begin{array}{l}0.45 \\
(0.0139)\end{array}$ & $\begin{array}{l}0.35 \\
(0.0709)\end{array}$ & $\begin{array}{l}0.27 \\
(0.1785)\end{array}$ \\
\hline Castilla-León & $\begin{array}{l}1.20 \\
(0.0000)\end{array}$ & $\begin{array}{l}0.79 \\
(0.0000)\end{array}$ & $\begin{array}{l}0.77 \\
(0.0000)\end{array}$ & $\begin{array}{l}0.45 \\
(0.0139)\end{array}$ & $\begin{array}{l}0.23 \\
(0.2875)\end{array}$ & $\begin{array}{l}0.17 \\
(0.4016)\end{array}$ \\
\hline Castilla-La Mancha & $\begin{array}{l}1.20 \\
(0.0000)\end{array}$ & $\begin{array}{l}0.79 \\
(0.0000)\end{array}$ & $\begin{array}{l}0.77 \\
(0.0000)\end{array}$ & $\begin{array}{l}0.45 \\
(0.0139)\end{array}$ & $\begin{array}{l}0.56 \\
(0.0037)\end{array}$ & $\begin{array}{l}0.36 \\
(0.0766)\end{array}$ \\
\hline Cataluña & $\begin{array}{l}1.20 \\
(0.0000)\end{array}$ & $\begin{array}{l}0.79 \\
(0.0000)\end{array}$ & $\begin{array}{l}0.77 \\
(0.0000)\end{array}$ & $\begin{array}{l}0.45 \\
(0.0139)\end{array}$ & $\begin{array}{l}0.61 \\
(0.0027)\end{array}$ & $\begin{array}{l}-0.01 \\
(0.9597)\end{array}$ \\
\hline Comunidad Valenciana & $\begin{array}{l}1.20 \\
(0.0000)\end{array}$ & $\begin{array}{l}0.79 \\
(0.0000)\end{array}$ & $\begin{array}{l}0.77 \\
(0.0000)\end{array}$ & $\begin{array}{l}0.45 \\
(0.0139)\end{array}$ & $\begin{array}{l}0.59 \\
(0.0047)\end{array}$ & $\begin{array}{l}0.22 \\
(0.3192)\end{array}$ \\
\hline Extremadura & $\begin{array}{l}1.20 \\
(0.0000)\end{array}$ & $\begin{array}{l}0.79 \\
(0.0000)\end{array}$ & $\begin{array}{l}0.77 \\
(0.0000)\end{array}$ & $\begin{array}{l}0.45 \\
(0.0139)\end{array}$ & $\begin{array}{l}0.54 \\
(0.0057)\end{array}$ & $\begin{array}{l}-0.14 \\
(0.5238)\end{array}$ \\
\hline Galicia & $\begin{array}{l}1.20 \\
(0.0000)\end{array}$ & $\begin{array}{l}0.79 \\
(0.0000)\end{array}$ & $\begin{array}{l}0.77 \\
(0.0000)\end{array}$ & $\begin{array}{l}0.45 \\
(0.0139)\end{array}$ & $\begin{array}{l}0.64 \\
(0.0040)\end{array}$ & $\begin{array}{l}-0.24 \\
(0.2478)\end{array}$ \\
\hline Madrid & $\begin{array}{l}1.00 \\
(-)\end{array}$ & $\begin{array}{l}1.00 \\
(-)\end{array}$ & $\begin{array}{l}0.77 \\
(0.0000)\end{array}$ & $\begin{array}{l}0.45 \\
(0.0139)\end{array}$ & $\begin{array}{l}0.69 \\
(0.0008)\end{array}$ & $\begin{array}{l}0.49 \\
(0.0065)\end{array}$ \\
\hline Murcia & $\begin{array}{l}1.20 \\
(0.0000)\end{array}$ & $\begin{array}{l}0.79 \\
(0.0000)\end{array}$ & $\begin{array}{l}0.77 \\
(0.0000)\end{array}$ & $\begin{array}{l}0.45 \\
(0.0139)\end{array}$ & $\begin{array}{l}0.59 \\
(0.0024)\end{array}$ & $\begin{array}{l}0.10 \\
(0.5060)\end{array}$ \\
\hline Navarra & $\begin{array}{l}1.20 \\
(0.0000)\end{array}$ & $\begin{array}{l}0.79 \\
(0.0000)\end{array}$ & $\begin{array}{l}0.77 \\
(0.0000)\end{array}$ & $\begin{array}{l}0.45 \\
(0.0139)\end{array}$ & $\begin{array}{l}0.53 \\
(0.0054)\end{array}$ & $\begin{array}{l}0.08 \\
(0.6071)\end{array}$ \\
\hline País Vasco & $\begin{array}{l}1.20 \\
(0.0000)\end{array}$ & $\begin{array}{l}0.79 \\
(0.0000)\end{array}$ & $\begin{array}{l}0.77 \\
(0.0000)\end{array}$ & $\begin{array}{l}0.45 \\
(0.0139)\end{array}$ & $\begin{array}{l}0.73 \\
(0.0000)\end{array}$ & $\begin{array}{l}-0.06 \\
(0.7049)\end{array}$ \\
\hline Rioja (La) & $\begin{array}{l}1.20 \\
(0.0000)\end{array}$ & $\begin{array}{l}0.79 \\
(0.0000)\end{array}$ & $\begin{array}{l}0.77 \\
(0.0000)\end{array}$ & $\begin{array}{l}0.45 \\
(0.0139)\end{array}$ & $\begin{array}{l}0.77 \\
(0.0000)\end{array}$ & $\begin{array}{l}0.08 \\
(0.6954)\end{array}$ \\
\hline
\end{tabular}

Notes: $P$-values in parenthesis.

The null hypotheses are:

$\mathrm{H}_{0}: \gamma=0$

$\mathrm{H}_{0}: \alpha=0$

$\mathrm{H}_{0}: \beta_{i}=0$

Source: Fundación BBVA and own elaboration.

asymmetric disturbances. However, following Karras (1996), who analyses the European Union case at a national level, we can ask whether specific shocks do or do not behave in practice as asymmetric shocks. In effect, it could be the case that specific shocks in certain regions are highly correlated and, in this case, they would behave as symmetric disturbances. Accordingly, we have computed the correlation coefficient among specific shocks of the 17 Spanish 
Table 5. Common shocks and asymmetric effects

\begin{tabular}{|c|c|c|}
\hline Regions & GAV & Prices \\
\hline Andalucía & $\begin{array}{l}1.11 \\
(0.7371)\end{array}$ & $\begin{array}{l}0.93 \\
(0.0878)\end{array}$ \\
\hline Aragón & $\begin{array}{l}1.34 \\
(0.5127)\end{array}$ & $\begin{array}{l}0.79 \\
(0.9741)\end{array}$ \\
\hline Asturias & $\begin{array}{l}0.72 \\
(0.1221)\end{array}$ & $\begin{array}{l}0.61 \\
(0.2505)\end{array}$ \\
\hline Baleares & $\begin{array}{l}1.23 \\
(0.8549)\end{array}$ & $\begin{array}{l}0.99 \\
(0.1391)\end{array}$ \\
\hline Canarias & $\begin{array}{l}1.22 \\
(0.9110)\end{array}$ & $\begin{array}{l}1.01 \\
(0.0185)\end{array}$ \\
\hline Cantabria & $\begin{array}{l}1.25 \\
(0.7942)\end{array}$ & $\begin{array}{l}0.70 \\
(0.0858)\end{array}$ \\
\hline Castilla-León & $\begin{array}{c}0.91 \\
(0.2636)\end{array}$ & $\begin{array}{c}0.79 \\
(0.9604)\end{array}$ \\
\hline Castilla-La Mancha & $\begin{array}{l}1.18 \\
(0.9385)\end{array}$ & $\begin{array}{l}0.70 \\
(0.1081)\end{array}$ \\
\hline Cataluña & $\begin{array}{l}1.47 \\
(0.2289)\end{array}$ & $\begin{array}{l}0.86 \\
(0.0762)\end{array}$ \\
\hline Comunidad Valenciana & $\begin{array}{l}1.43 \\
(0.2763)\end{array}$ & $\begin{array}{l}0.78 \\
(0.8413)\end{array}$ \\
\hline Extremadura & $\begin{array}{l}0.83 \\
(0.2486)\end{array}$ & $\begin{array}{l}0.79 \\
(0.9638)\end{array}$ \\
\hline Galicia & $\begin{array}{l}1.10 \\
(0.6390)\end{array}$ & $\begin{array}{l}0.74 \\
(0.5109)\end{array}$ \\
\hline Madrid & $\begin{array}{l}1.00 \\
(-)\end{array}$ & $\begin{array}{l}1.00 \\
(-)\end{array}$ \\
\hline Murcia & $\begin{array}{l}1.04 \\
(0.5128)\end{array}$ & $\begin{array}{l}0.80 \\
(0.8436)\end{array}$ \\
\hline Navarra & $\begin{array}{l}1.23 \\
(0.8161)\end{array}$ & $\begin{array}{l}0.75 \\
(0.6018)\end{array}$ \\
\hline País Vasco & $\begin{array}{l}1.18 \\
(0.9466)\end{array}$ & $\begin{array}{l}0.68 \\
(0.1628)\end{array}$ \\
\hline Rioja (La) & $\begin{array}{l}0.98 \\
(0.3392)\end{array}$ & $\begin{array}{l}0.84 \\
(0.4307)\end{array}$ \\
\hline
\end{tabular}

Notes: $P$-values in parenthesis.

The null hypotheses are:

$\mathrm{H}_{0}: \gamma_{i}=1,20$

$\mathrm{H}_{0}: \gamma_{i}=0,79$

Source: Fundación BBVA and own elaboration.

regions, taken on a two-by-two basis. Results are displayed in Table 6 for output and Table 7 for prices.

As regards output, there are a remarkable number of coefficients that are significantly different from zero. However, there is not enough evidence to conclude that the specific shocks have asymmetric effects. It can be pointed out, though, that some regions seem to suffer disturbances that are not in line with those observed in the rest of the country (e.g. Comunidad Valenciana displays negative signs of the correlation coefficients).

As far as prices are concerned (Table 7) the findings show that a larger number of correlation coefficients than for output are significant. Moreover, negative signs are relatively more 
Table 6. Specific shocks and symmetric effects (GAV)

\begin{tabular}{|c|c|c|c|c|c|c|c|c|c|c|c|c|c|c|c|c|c|}
\hline & Andalucía & Aragón & Asturias & Baleares & Canarias & Cantabria & $\begin{array}{l}\text { Castilla- } \\
\text { León }\end{array}$ & $\begin{array}{l}\text { Castilla- } \\
\text { La } \\
\text { Mancha }\end{array}$ & Cataluña & $\begin{array}{l}\text { Comunidad } \\
\text { Valenciana }\end{array}$ & Extremadura & Galicia & Madrid & Murcia & Navarra & $\begin{array}{l}\text { País } \\
\text { Vasco }\end{array}$ & $\begin{array}{l}\text { Rioja } \\
\text { (La) }\end{array}$ \\
\hline Andalucía & 1.00 & & & & & & & & & & & & & & & & \\
\hline Aragón & $-0.31^{*}$ & 1.00 & & & & & & & & & & & & & & & \\
\hline Asturias & $-0.41^{*}$ & $0.39^{*}$ & 1.00 & & & & & & & & & & & & & & \\
\hline Baleares & 0.03 & 0.11 & $0.29^{*}$ & 1.00 & & & & & & & & & & & & & \\
\hline Canarias & 0.00 & 0.06 & 0.02 & 0.20 & 1.00 & & & & & & & & & & & & \\
\hline Cantabria & -0.22 & 0.03 & 0.17 & 0.06 & -0.23 & 1.00 & & & & & & & & & & & \\
\hline Castilla-León & 0.22 & -0.04 & 0.14 & $-0.34^{*}$ & $0.31^{*}$ & $-0.28^{*}$ & 1.00 & & & & & & & & & & \\
\hline Castilla-La Mancha & $0.49^{*}$ & -0.12 & -0.10 & $-0.38^{*}$ & 0.22 & -0.24 & $0.60^{*}$ & 1.00 & & & & & & & & & \\
\hline Cataluña & 0.17 & -0.05 & -0.02 & $0.39^{*}$ & $-0.51^{*}$ & 0.20 & $-0.42^{*}$ & $-0.50^{*}$ & 1.00 & & & & & & & & \\
\hline \multicolumn{18}{|l|}{ Comunidad } \\
\hline Valenciana & 0.08 & -0.17 & $-0.32^{*}$ & 0.14 & -0.19 & 0.17 & $-0.31^{*}$ & 0.02 & 0.21 & 1.00 & & & & & & & \\
\hline Extremadura & $0.43^{*}$ & 0.07 & -0.04 & -0.20 & $0.58^{*}$ & $-0.34^{*}$ & $0.62^{*}$ & $0.55^{*}$ & $-0.30^{*}$ & -0.25 & 1.00 & & & & & & \\
\hline Galicia & 0.23 & -0.04 & -0.09 & $-0.48^{*}$ & 0.10 & -0.02 & $0.38^{*}$ & $0.59^{*}$ & $-0.53^{*}$ & 0.21 & 0.17 & 1.00 & & & & & \\
\hline Madrid & -0.06 & -0.10 & $0.51^{*}$ & 0.10 & 0.09 & 0.00 & $0.40^{*}$ & -0.01 & 0.22 & $-0.41^{*}$ & 0.25 & $-0.29^{*}$ & 1.00 & & & & \\
\hline Murcia & 0.24 & -0.06 & 0.14 & -0.24 & 0.18 & -0.10 & $0.37^{*}$ & $0.56^{*}$ & -0.13 & $-0.27^{*}$ & $0.31^{*}$ & $0.33^{*}$ & 0.17 & 1.00 & & & \\
\hline Navarra & -0.07 & 0.22 & -0.01 & -0.04 & $-0.46^{*}$ & 0.12 & -0.20 & $-0.34^{*}$ & 0.23 & -0.08 & $-0.38^{*}$ & -0.03 & -0.14 & $-0.35^{*}$ & 1.00 & & \\
\hline País Vasco & -0.24 & 0.09 & $0.28^{*}$ & 0.06 & $-0.69^{*}$ & 0.20 & -0.14 & $-0.40^{*}$ & $0.54^{*}$ & -0.10 & $-0.50^{*}$ & $-0.30^{*}$ & $0.38^{*}$ & -0.21 & $0.65^{*}$ & 1.00 & \\
\hline Rioja (La) & 0.00 & $0.36^{*}$ & -0.07 & -0.24 & 0.02 & $-0.29^{*}$ & 0.01 & 0.20 & -0.18 & $-0.29^{*}$ & 0.08 & $0.30^{*}$ & -0.14 & 0.13 & $0.41^{*}$ & 0.08 & 1.00 \\
\hline
\end{tabular}


Table 7. Specific shocks and symmetric effects (prices)

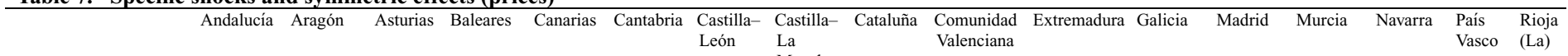

\begin{tabular}{|c|c|c|c|c|c|c|c|c|c|c|c|c|c|c|c|c|c|}
\hline Andalucía & 1.00 & & & & & & & & & & & & & & & & \\
\hline Aragón & $-0.47^{*}$ & 1.00 & & & & & & & & & & & & & & & \\
\hline Asturias & 0.26 & $-0.28^{*}$ & 1.00 & & & & & & & & & & & & & & \\
\hline Baleares & 0.05 & $0.37^{*}$ & $-0.43^{*}$ & 1.00 & & & & & & & & & & & & & \\
\hline Canarias & 0.18 & $-0.54^{*}$ & $0.38^{*}$ & $-0.66^{*}$ & 1.00 & & & & & & & & & & & & \\
\hline Cantabria & -0.15 & $0.35^{*}$ & -0.08 & $0.43^{*}$ & $-0.68^{*}$ & 1.00 & & & & & & & & & & & \\
\hline Castilla-León & $0.55^{*}$ & $-0.41^{*}$ & $0.58^{*}$ & $-0.54^{*}$ & $0.56^{*}$ & $-0.41^{*}$ & 1.00 & & & & & & & & & & \\
\hline Castilla-La Mancha & $0.38^{*}$ & $-0.44^{*}$ & -0.07 & -0.08 & $0.28^{*}$ & -0.25 & $0.57^{*}$ & 1.00 & & & & & & & & & \\
\hline Cataluña & -0.08 & $0.62^{*}$ & $-0.28^{*}$ & $0.71^{*}$ & $-0.58^{*}$ & 0.24 & $-0.54^{*}$ & $-0.59^{*}$ & 1.00 & & & & & & & & \\
\hline Comunidad Valenciana & $-0.40^{*}$ & $0.38^{*}$ & -0.13 & -0.16 & -0.06 & 0.08 & $-0.32^{*}$ & $-0.47^{*}$ & 0.01 & 1.00 & & & & & & & \\
\hline Extremadura & $-0.48^{*}$ & 0.05 & $-0.46^{*}$ & -0.16 & 0.08 & -0.25 & $-0.36^{*}$ & -0.15 & -0.08 & $0.64^{*}$ & 1.00 & & & & & & \\
\hline Galicia & $-0.41^{*}$ & $0.84^{*}$ & $-0.59^{*}$ & $0.65^{*}$ & $-0.64^{*}$ & $0.35^{*}$ & $-0.64^{*}$ & $-0.37^{*}$ & $0.72^{*}$ & $0.27^{*}$ & 0.14 & 1.00 & & & & & \\
\hline Madrid & $-0.31^{*}$ & -0.16 & $-0.54^{*}$ & 0.01 & -0.18 & -0.08 & $-0.52^{*}$ & $-0.28^{*}$ & 0.14 & 0.05 & $0.36^{*}$ & 0.12 & 1.00 & & & & \\
\hline Murcia & $0.59^{*}$ & $-0.64^{*}$ & $0.36^{*}$ & -0.21 & $0.67^{*}$ & $-0.59^{*}$ & $0.58^{*}$ & $0.39^{*}$ & $-0.37^{*}$ & -0.06 & -0.02 & $-0.61^{*}$ & $-0.26^{*}$ & 1.00 & & & \\
\hline Navarra & 0.00 & -0.24 & -0.03 & -0.05 & $-0.42^{*}$ & $0.45^{*}$ & -0.02 & $0.27^{*}$ & $-0.34^{*}$ & $-0.29^{*}$ & -0.19 & -0.17 & 0.16 & $-0.39^{*}$ & 1.00 & & \\
\hline País Vasco & $-0.27^{*}$ & 0.25 & 0.08 & 0.09 & $-0.56^{*}$ & $0.47^{*}$ & $-0.28^{*}$ & -0.23 & 0.15 & $-0.27^{*}$ & $-0.32^{*}$ & 0.13 & 0.07 & $-0.73^{*}$ & $0.62^{*}$ & 1.00 & \\
\hline Rioja (La) & $-0.68^{*}$ & 0.14 & $-0.32^{*}$ & -0.14 & 0.13 & -0.05 & $-0.32^{*}$ & 0.12 & $-0.27^{*}$ & 0.10 & $0.36^{*}$ & 0.21 & 0.17 & $-0.37^{*}$ & 0.14 & 0.07 & 1.00 \\
\hline
\end{tabular}

Note: *significant at 95\%. Source: Fundación BBVA and own elaboration. 
abundant. Hence it could be tentatively concluded that specific shocks seem to be asymmetric. In particular, Castilla-La Mancha is the region in which shocks appear to be more asymmetric: for this region, the correlation coefficient is negative and significant in eight cases.

\section{Concluding remarks}

This paper has tried to ascertain whether the probability of Spanish regions experiencing asymmetric shocks is high. Additionally, it has analyzed the persistence and the origin of both symmetric and asymmetric shocks. To do that, we have applied a State Space methodology, rich enough so as to offer interesting insights on this issue. According to our estimates, the basic findings of the paper can be summarized as follows: the shocks that have impinged on Spanish regions between 1955 and 1997 have been mostly symmetric (less on output than on prices), persistent (less on prices than on output) and more driven by supply than demand factors.

Finally, two possible extensions of the paper seem to be indicated. On one hand, the estimation methodology can be applied to other situations, mainly to the European regional case. On the other hand, the paper could be extended to evaluate the ability of the Spanish regions to respond to different types of shocks.

The authors would like to thank Per Jansson, Anthony Leddin, Blanca Sánchez-Robles, Enrique López-Bazo and two anonymous referees for helpful comments and suggestions.

Final version received January 2005.

Send correspondence to Adolfo Maza: mazaaj@unican.es

\section{References}

Bayoumi, T. and Eichengreen, B. 1993. Shocking Aspects of European Monetary Unification. In: Giavazzi, F. and Torres, F. (eds), The Transition to Economic and Monetary Union in Europe. Cambridge: Cambridge University Press.

Bayoumi, T. and Taylor, M. 1992. Macroeconomic shocks, the ERM, and tri-polarity, Discussion Paper 711. London: Centre for Economic Policy Research (CEPR).

Bean, C.R. 1992. Economic and Monetary Union in Europe. Journal of Economic Perspectives 6, 31-52.

Blanchard, O. and Quah, D. 1989. The Dynamic Effects of Aggregate Demand and Supply Disturbances. American Economic Review 79, 655-673.

Blanchard, O. and Wolfers, J. 1999. The Role of Shocks and Institutions in the Rise of European Unemployment: The Aggregate Evidence. Working paper 7284. Cambridge: National Bureau of Economic Research (NBER).

Cohen, D. and Wyplosz, C. 1989. The European Monetary Union: An Agnostic Evaluation. Discussion Paper 306. London: Centre for Economic Policy Research (CEPR).

Emerson, M., Gros, D., Italianer, A., Pisani-Ferry, J. and Reichenbach, H. 1992. One Market, One Money. Oxford: Oxford University Press.

Fatás, A. 1997. EMU: Countries or Regions? Lessons from the EMS Experience. European Economic Review 41, 743-751.

Gregory, A.W., Head, A.C. and Raynauld, J. 1997. Measuring World Business Cycles. International Economic Review 38, 677-701.

Hamilton, J.D. 1994. Time Series Analysis. Princeton, NJ: Princeton University Press.

Harvey, A. 1989. Forecasting, Structural Time Series Models and the Kalman Filter. Cambridge: Cambridge University Press.

Harvey, A. 1990. The Econometric Analysis of Time Series. London: Philip Allan. 
Jansson, P. 1997. How Large is the Risk of Asymmetric Shocks for Sweden? Swedish Economic Policy Review 4, 447-486.

Karras, G. 1996. Is Europe an Optimum Currency Area? Evidence on the Magnitude and Asymmetry of Common and Country-specific Shocks in 20 European Countries. Journal of Economic Integration $11,366-384$.

Maza, A., Moral-Arce, I. 2005. An Analysis of Wage Flexibility: Evidence from the Spanish Regions. Annals of Regional Science (forthcoming)

Maza, A., Villaverde, J. 2004. Interregional Migration: New Analysis Techniques for the Spanish Case. Review of Regional Studies 34, (forthcoming)

Myro, R. and Perelli, O. 1996. Convergencia Regional y Flexibilidad de Precios. Información Comercial Española 756, 89-101.

Obstfeld, M. and Peri, G. 1998. Regional Non-adjustment and Fiscal Policy. Economic Policy 13, 207-259.

Sánchez-Robles, B. and Cuñado, J. 1999. Perturbaciones asimétricas y Unión Monetaria Europea: Las Regiones Españolas. Papeles de Economía Española 80, 152-170. 


\section{Appendix: Model diagnosis}

In this appendix the statistical properties of the model are covered in more detail as regards normality, serial correlation, homocedasticity and stability of parameters. Table A1 displays the main results. Generally speaking, these results suggest that the model is correctly specified.

Table A1. Specification tests

\begin{tabular}{|c|c|c|c|c|c|c|c|c|}
\hline \multirow[t]{2}{*}{ Region } & \multicolumn{2}{|c|}{ Normality } & \multicolumn{2}{|c|}{ Autocorrelation } & \multicolumn{2}{|c|}{ Heterocedasticity } & \multicolumn{2}{|c|}{ Stable parameters } \\
\hline & GAV & Prices & GAV & Prices & GAV & Prices & GAV & Prices \\
\hline Andalucía & $\begin{array}{c}0.21 \\
(0.90)\end{array}$ & $\begin{array}{c}5.78 \\
(0.06)\end{array}$ & $\begin{array}{c}6.22 \\
(0.19)\end{array}$ & $\begin{array}{c}2.60 \\
(0.63)\end{array}$ & $\begin{array}{c}1.01 \\
(0.32)\end{array}$ & $\begin{array}{c}1.88 \\
(0.17)\end{array}$ & Yes & Yes \\
\hline Aragón & $\begin{array}{c}4.34 \\
(0.12)\end{array}$ & $\begin{array}{c}2.82 \\
(0.25)\end{array}$ & $\begin{array}{c}4.39 \\
(0.36)\end{array}$ & $\begin{array}{c}3.75 \\
(0.44)\end{array}$ & $\begin{array}{c}1.24 \\
(0.26)\end{array}$ & $\begin{array}{c}4.50 \\
(0.04)\end{array}$ & Yes & Yes \\
\hline Asturias & $\begin{array}{c}4.14 \\
(0.13)\end{array}$ & $\begin{array}{c}0.08 \\
(0.96)\end{array}$ & $\begin{array}{l}12.11 \\
(0.02)\end{array}$ & $\begin{array}{l}13.34 \\
(0.01)\end{array}$ & $\begin{array}{c}0.67 \\
(0.41)\end{array}$ & $\begin{array}{c}0.26 \\
(0.61)\end{array}$ & Yes & Yes \\
\hline Baleares & $\begin{array}{c}5.69 \\
(0.06)\end{array}$ & $\begin{array}{c}7.93 \\
(0.02)\end{array}$ & $\begin{array}{c}3.08 \\
(0.55)\end{array}$ & $\begin{array}{l}14.35 \\
(0.01)\end{array}$ & $\begin{array}{c}0.05 \\
(0.82)\end{array}$ & $\begin{array}{c}1.72 \\
(0.19)\end{array}$ & Yes & Yes \\
\hline Canarias & $\begin{array}{c}3.87 \\
(0.14)\end{array}$ & $\begin{array}{c}2.86 \\
(0.24)\end{array}$ & $\begin{array}{c}6.39 \\
(0.17)\end{array}$ & $\begin{array}{c}7.70 \\
(0.10)\end{array}$ & $\begin{array}{c}0.01 \\
(0.95)\end{array}$ & $\begin{array}{c}2.94 \\
(0.09)\end{array}$ & Yes & Yes \\
\hline Cantabria & $\begin{array}{c}3.42 \\
(0.18)\end{array}$ & $\begin{array}{c}1.31 \\
(0.52)\end{array}$ & $\begin{array}{l}19.28 \\
(0.00)\end{array}$ & $\begin{array}{c}3.07 \\
(0.55)\end{array}$ & $\begin{array}{c}2.22 \\
(0.14)\end{array}$ & $\begin{array}{c}5.98 \\
(0.02)\end{array}$ & Yes & Yes \\
\hline Castilla-León & $\begin{array}{c}9.87 \\
(0.01)\end{array}$ & $\begin{array}{c}0.47 \\
(0.80)\end{array}$ & $\begin{array}{l}15.03 \\
(0.01)\end{array}$ & $\begin{array}{c}5.83 \\
(0.25)\end{array}$ & $\begin{array}{c}3.69 \\
(0.06)\end{array}$ & $\begin{array}{c}1.86 \\
(0.17)\end{array}$ & Yes & Yes \\
\hline Castilla-La Mancha & $\begin{array}{c}1.20 \\
(0.55)\end{array}$ & $\begin{array}{c}1.71 \\
(0.43)\end{array}$ & $\begin{array}{c}9.23 \\
(0.06)\end{array}$ & $\begin{array}{c}2.48 \\
(0.65)\end{array}$ & $\begin{array}{c}1.52 \\
(0.22)\end{array}$ & $\begin{array}{c}2.81 \\
(0.09)\end{array}$ & Yes & Yes \\
\hline Cataluña & $\begin{array}{c}3.84 \\
(0.15)\end{array}$ & $\begin{array}{c}2.43 \\
(0.30)\end{array}$ & $\begin{array}{c}4.88 \\
(0.30)\end{array}$ & $\begin{array}{c}4.25 \\
(0.37)\end{array}$ & $\begin{array}{c}0.79 \\
(0.38)\end{array}$ & $\begin{array}{c}3.32 \\
(0.07)\end{array}$ & Yes & Yes \\
\hline C. Valenciana & $\begin{array}{c}1.63 \\
(0.44)\end{array}$ & $\begin{array}{c}2.45 \\
(0.29)\end{array}$ & $\begin{array}{c}5.63 \\
(0.23)\end{array}$ & $\begin{array}{c}2.49 \\
(0.65)\end{array}$ & $\begin{array}{c}1.83 \\
(0.18)\end{array}$ & $\begin{array}{c}2.97 \\
(0.09)\end{array}$ & Yes & Yes \\
\hline Extremadura & $\begin{array}{c}7.22 \\
(0.03)\end{array}$ & $\begin{array}{c}5.51 \\
(0.06)\end{array}$ & $\begin{array}{c}6.86 \\
(0.14)\end{array}$ & $\begin{array}{c}3.41 \\
(0.49)\end{array}$ & $\begin{array}{c}0.11 \\
(0.74)\end{array}$ & $\begin{array}{c}0.72 \\
(0.40)\end{array}$ & Yes & Yes \\
\hline Galicia & $\begin{array}{c}0.16 \\
(0.92)\end{array}$ & $\begin{array}{c}6.46 \\
(0.04)\end{array}$ & $\begin{array}{l}10.42 \\
(0.04)\end{array}$ & $\begin{array}{c}5.36 \\
(0.25)\end{array}$ & $\begin{array}{c}4.85 \\
(0.03)\end{array}$ & $\begin{array}{c}0.68 \\
(0.41)\end{array}$ & Yes & Yes \\
\hline Madrid & $\begin{array}{c}2.61 \\
(0.27)\end{array}$ & $\begin{array}{c}0.86 \\
(0.65)\end{array}$ & $\begin{array}{l}17.26 \\
(0.01)\end{array}$ & $\begin{array}{c}4.88 \\
(0.30)\end{array}$ & $\begin{array}{c}2.72 \\
(0.10)\end{array}$ & $\begin{array}{c}2.59 \\
(0.11)\end{array}$ & Yes & Yes \\
\hline Murcia & $\begin{array}{c}0.41 \\
(0.81)\end{array}$ & $\begin{array}{c}3.59 \\
(0.17)\end{array}$ & $\begin{array}{c}7.11 \\
(0.13)\end{array}$ & $\begin{array}{c}3.27 \\
(0.51)\end{array}$ & $\begin{array}{c}1.52 \\
(0.22)\end{array}$ & $\begin{array}{c}2.14 \\
(0.14)\end{array}$ & Yes & Yes \\
\hline Navarra & $\begin{array}{c}1.08 \\
(0.58)\end{array}$ & $\begin{array}{c}1.16 \\
(0.56)\end{array}$ & $\begin{array}{c}4.83 \\
(0.31)\end{array}$ & $\begin{array}{c}7.26 \\
(0.12)\end{array}$ & $\begin{array}{c}8.97 \\
(0.01)\end{array}$ & $\begin{array}{c}1.38 \\
(0.24)\end{array}$ & Yes & Yes \\
\hline País Vasco & $\begin{array}{c}0.19 \\
(0.91)\end{array}$ & $\begin{array}{c}2.15 \\
(0.34)\end{array}$ & $\begin{array}{c}2.97 \\
(0.56)\end{array}$ & $\begin{array}{c}8.81 \\
(0.07)\end{array}$ & $\begin{array}{c}2.71 \\
(0.10)\end{array}$ & $\begin{array}{c}0.70 \\
(0.40)\end{array}$ & Yes & Yes \\
\hline Rioja (La) & $\begin{array}{c}3.88 \\
(0.14)\end{array}$ & $\begin{array}{c}1.64 \\
(0.44)\end{array}$ & $\begin{array}{c}4.34 \\
(0.36)\end{array}$ & $\begin{array}{c}3.63 \\
(0.46)\end{array}$ & $\begin{array}{c}3.21 \\
(0.07)\end{array}$ & $\begin{array}{c}2.60 \\
(0.11)\end{array}$ & Yes & Yes \\
\hline
\end{tabular}

Notes: $P$-values in parenthesis.

The null hypotheses are:

$\mathrm{H}_{0}:$ normality

$\mathrm{H}_{0}:$ no serial correlation

$\mathrm{H}_{0}$ : homocedasticity.

Test for normality: Doornik and Hansen. Test for serial correlation: Ljung and Box (autocorrelation up to 5 lags). Test for heterocedasticity: Engle's ARCH test. Test for stability of parameters: Brown, Durbin and Evans. 'Yes' indicates that the null can not be rejected at the $95 \%$ level. 